\title{
STRUKTUR KOMUNITAS KEPITING BIOLA (Uca spp.) DI EKOSISTEM MANGROVE DESA KAHYAPU PULAU ENGGANO
}

\author{
Oleh \\ Trya Natania, N. Ervina Herliany, Aradea Bujana Kusuma \\ Program Studi Ilmu Kelautan, Fakultas Pertanian Universitas Bengkulu, Bengkulu \\ Email: tryanatania@gmail.com \\ Received January 2017 Accepted March 2017
}

\begin{abstract}
ABSTRAK
Mangrove merupakan ekosistem kompleks yang hidup di daerah pasang surut. Ekosistem mangrove selain melindungi pantai dari gelombang dan angin juga sebagai habitat berbagai organisme seperti krustasea. Salah satu krustasea yang memiliki peran penting di ekosistem mangrove adalah kepiting biola (Uca spp.) sebagai detritus di ekosistem mangrove. Pulau Enggano merupakan pulau kecil terluar Provinsi Bengkulu, keadaan ekosistem mangrovenya masih tergolong alami. Salah satu desa yang memiliki vegetasi mangrove yang alami adalah Desa Kahyapu. Tetapi penelitian tentang Uca spp. di Pulau Enggano khususnya di Desa Kahyapu belum pernah dilakukan. Tujuan dari kegiatan penelitian ini adalah mengidentifikasi jenis kepiting biola dan menganalisis struktur komunitas kepiting biola di Desa Kahyapu Pulau Enggano. Penelitian ini menggunakan metode survei dengan menggunakan teknik observasi langsung pada 3 stasiun, dimana setiap stasiun terdiri dari 11 plot. Dari hasil penelitian didapatkan 4 jenis kepiting biola (Uca spp.) yaitu Uca vocans, Uca chlorophthalmus, Uca dussumeiri, dan Uca coarctata. Kelimpahan jenis kepiting biola (Uca spp.) yang paling tinggi pada stasiun I. Kelimpahan total tertinggi terdapat pada stasiun I dan diikuti stasiun III, terendah pada stasiun II. Tingginya kelimpahan pada stasiun I diduga karena substrat liat yang cocok untuk kehidupan kepiting biola. Secara umum Uca dussumieri paling banyak ditemukan di tiga stasiun karena toleransinya yang tinggi . Indeks keseragaman kepiting biola (Uca spp.) seluruh stasiun tinggi sedangkan indeks keanekaragamannya rendah. Pada stasiun I dan II mempunyai indeks dominansi rendah, sedangkan pada stasiun III mempunai indeks dominansi sedang. Secara umum, kualitas perairan (suhu, pH, salinitas, kandungan bahan organik, dan substrat) di lokasi penelitian cocok untuk kehidupan Uca spp.
\end{abstract}

Kata kunci: Struktur komunitas, habitat, kepiting biola (Uca spp.), Kahyapu Pulau Enggano.

\begin{abstract}
Mangrove is a complex ecosystem that lives in tidal areas. The mangrove ecosystem in addition to protecting the beach from waves and wind as well as a habitat for many organisms such as crustaceans. One of the crustaceans that have an important role in the mangrove ecosystem is fiddler crab (Uca spp.), as detritus in mangrove ecosystems. Enggano is a small island of Bengkulu Province that has mangrove ecosystem in a good condition. One of the village that has a natural mangrove
\end{abstract}


vegetation is Kahyapu village. But the studies of Uca spp. in Enggano particularly in the Village Kahyapu has never done before. The purpose of this research is to identify the species of fiddler crab and analyze community structure of fiddler crab in Kahyapu village, Enggano. This study used a survey method using direct observation techniques at three stations, where each station consists of 11 plots. The results showed there are four kinds of fiddler crabs (Uca spp.), which are Uca vocans, Uca chlorophthalmus, Uca dussumeiri, and Uca coarctata. Station I has the highest abundance of fiddler crabs (Uca spp.) because the substrate (clay) was suitable for fiddler crab. The total abundance of fiddler crabs in all station are station I, station III, and station II, respectively. Generally, Uca dussumieri most commonly found in three stations due to their high tolerance. All stations have high criteria of uniformity index but have low criteria of diversity index. At the station I and II have low criteria of dominance index, while the station III have medium citeria of dominance index. The water quality parameters (temperature, $\mathrm{pH}$, salinity, organic matter content, and substrate) at the study area were good for Uca spp.

Keywords: community structure, habitat, fiddler crabs (Uca spp.), Kahyapu, Enggano.

\section{PENDAHULUAN}

Mangrove merupakan ekosistem yang kompleks terdiri atas flora dan fauna daerah pantai, hidup sekaligus di habitat daratan dan air laut, antara batas air pasang dan surut. Ekosistem mangrove selain melindungi pantai dari gelombang dan angin juga sebagai tempat yang dipenuhi pula oleh kehidupan lain seperti mamalia, burung, ikan, dan crustacea. Salah satu crustacea yang hidup di mangrove adalah Uca spp.

Kepiting Uca spp. sering juga disebut dengan kepiting biola. Nama kepiting biola berasal dari cara makan Uca spp. jantan. Gerakan capit kecil yang terus menerus dari substrat ke mulut dan kembali lagi ke substrat mirip dengan gerakan pemain biola saat menggerakkan busur ke biola (capit besar) (Rosenberg, 2000).

Kepiting biola yang hidup dalam lingkungan yang mendukung dapat bertahan hidup hingga mencapai umur 3-4 tahun. Kepiting biola yang berusia 12-14 bulan telah dapat melakukan proses perkembangbiakan. Uca spp. berperan sebagai pemakan detritus (detrititus) di ekosistem mangrove (Suprayogi, 2014). Kepiting biola (Uca spp.) ini juga memiliki nilai ekonomis yaitu kepiting biola (Uca spp.) banyak ditangkap dan dijual sebagai kepiting hiasan (Hamidah, 2014).

Habitat Uca spp. di daerah intertidal, terutama di sekitar hutan mangrove dan pantai berpasir. Kepiting ini ditemukan di pantai terlindung dekat teluk yang besar atau laut terbuka, kadang-kadang hanya terlindung oleh karang atau lumpur laut. Uca spp. merupakan salah satu kepiting kecil, semi-terrestrial yang memiliki peran penting dalam ekologi mangrove tropis (Pratiwi, 2007). Kepiting biola berperan dalam menjaga keseimbangan rantai makanan dan siklus nitrogen dalam ekosistem mangrove. Lubang kepiting meningkatkan aerasi, memudahkan pengeringan tanah, dan menunjang pertukaran unsur hara antara sedimen dan perairan pasang surut.

Senoaji $d k k$. (2006) menyatakan bahwa Pulau Enggano secara geografis berada di wilayah perairan Samudera Hindia dan terletak pada posisi 102,05을 hingga 102,25은 BT dan $5,1^{\circ}$ sampai $5,31^{\circ}$ LS. Keseluruhan wilayah daratan Pulau Enggano luasnya 
\pm 40.600 hektar. Sebagai sebuah kecamatan, Pulau Enggano terdiri dari 6 desa yaitu Desa Malakoni, Apoho, Meok, Banjarsari, Kaana dan Kahyapu. Sebagai suatu kepulauaan, Pulau Enggano memiliki pulau-pulau kecil di sekitarnya, yakni Pulau Merbau, Pulau Dua, Pulau Satu, dan Pulau Bangkai. Keadaan ekosistem mangrove di Pulau Enggano masih tergolong alami. Salah satu desa di Pulau Enggano yang ekosistem mangrove masih dalam kondisi bagus adalah di Desa Kahyapu. Desa Kahyapu merupakan salah satu desa di Pulau Enggano yang memiliki vegetasi ekosistem mangrove yang masih alami. Tetapi, data ilmiah tentang kondisi ekosistem mangrove di Desa Kahyapu masih sangat kurang.

Penelitian tentang Uca spp. di Provinsi Bengkulu telah dilakukan oleh Kasmiruddin dkk. (2014) di Pulau Baai. Hasan (2014) di kawasan konservasi mangrove Pantai Panjang dan Peddy dkk., (2014) dikawasan mangrove Desa Pasar Ngalam Kecamatan Air Periukan Kabupaten Seluma. Sedangkan penelitian tentang kepiting Uca spp. di Pulau Enggano khususnya di Desa Kahyapu belum pernah dilakukan. Berdasarkan latar belakang tersebut, maka penting dilakukan penelitian mengenai struktur komunitas kepiting biola (Uca spp.) yang terdapat di ekosistem mangrove Desa Kahyapu Pulau Enggano.

\section{Tujuan dan Manfaat Penelitian}

Tujuan dari kegiatan penelitian ini adalah mengidentifikasi jenis kepiting biola dan menganalisis struktur komunitas kepiting biola di Desa Kahyapu Pulau Enggano.

Manfaat dari penelitian ini adalah diharapkan data yang diperoleh dapat digunakan untuk melengkapi data fauna yang berasosiasi dengan ekosistem mangrove sebagai bahan pengelolaan ekosistem mangrove di Desa Kahyapu. Data hasil penelitian ini diharapkan dapat dijadikan sebagai referensi ataupun acuan untuk penelitian selanjutnya.

\section{MATERI DAN METODE}

\section{Waktu dan Tempat}

Penelitian ini dilaksanakan pada bulan Agustus 2016, yang berlokasi di Desa Kahyapu, Kecamatan Enggano, Kabupaten Bengkulu Utara Provinsi Bengkulu.

\section{Alat dan Bahan}

Alat yang digunakan dalam penelitian disajikan pada Tabel 1 . Tabel 1. Alat-alat yang digunakan dalam penelitian

\begin{tabular}{|c|c|c|}
\hline No. & Nama Alat & Fungsi \\
\hline 1. & $\mathrm{pH}$ meter & Digunakan untuk mengukur $\mathrm{pH}$ \\
\hline 2. & Buku identifikasi & $\begin{array}{l}\text { Sebagai acuan untuk mengidentifikasi jenis } \\
\text { kepiting biola (Uca spp.) }\end{array}$ \\
\hline 3. & Kamera & Untuk dokumentasi penelitian \\
\hline 4. & Laptop & enyimpan data hasil penelitian \\
\hline 5. & $\begin{array}{ll}\text { Global } & \text { Position } \\
\text { System (GPS) } & \end{array}$ & Sebagai alat penentu lokasi penelitian \\
\hline 6. & Refractometer & Untuk mengukur salinitas \\
\hline 7. & Meteran/Roll meteran & $\begin{array}{l}\text { Digunakan sebagai alat ukur pada penentuan jarak } \\
\text { anatara stasiun, garis transek, dan plot penelitian }\end{array}$ \\
\hline
\end{tabular}


8. Botol sampel

9. Termometer

10. Ayakan

11. Sekop Kecil

12. Alat Tulis

13. Oven
Digunakan sebagai tempat wadah yang akan dibawa untuk diteliti lebih lanjut Untuk mengukur suhu

Untuk menyarik substrat Untuk menangkap kepiting Uca spp.

Untuk melakukan pencatatan data saat melaksakan penelitian di lapangan Untuk mengeringkaan substrat

Bahan yang digunakan dalam penelitian pada Tabel 2 .

Tabel 2. Daftar Bahan yang digunakan dalam penelitian

No.

Nama Bahan

Fungsi

1. Kepiting Biola (Uca Sebagai bahan penelitian sp.)

2. Alkohol $70 \%$ Untuk mengawetkan kepiting

3. Tissue Untuk mengeringkan/mengelap alat pengukur kualitas air yang digunakan

4. Tali plastic Digunakan untuk pembuatan transek

Metode Penelitian

Penelitian ini menggunakan metode survei dengan menggunakan teknik observasi langsung dan penggunaan stasiun untuk plot setiap pengamatan. Pengukuran parameter lingkungan seperti suhu, salinitas, derajat keasaman $(\mathrm{pH})$, sedangkan untuk kandungan bahan organik dilakukan analisis di laboratorium.

\section{Penentuan Titik Stasiun Penelitian}

\section{Pengambilan Sampel}

Stasiun penelitian dilakukan pada 3 (tiga) stasiun yang berbeda (Gambar 3). Perbedaan tersebut dari dominansi mangrove yang ada pada masing - masing stasiun. Setiap stasiun dibuat 11 plot berukuran $1 \times 1 \mathrm{~m}^{2}$ (Gambar 4). Jalur transek pengamatan dimulai dengan arah mendatar dari arah horizontal searah dengan garis pantai dengan panjang transek $250 \mathrm{~m}$. Pengambilan sampel hanya dilakukan satu kali pada masing-masing plot. 3).

Lokasi penelitian di Desa Kahyapu Pulau Enggano memiliki karekteristik (Tabel Tabel 3. Karekteristik lokasi penelitian di Desa Kahyapu Pulau Enggano (Agustina, 2014)

\begin{tabular}{cc}
\hline Stasiun & Karakteristik Lokasi Penelitian \\
\hline 1 & Kondisi substratnya lebih berlumpur dan lokasi dekat dengan \\
2 & pemukiman dan aktifitas masyarakat \\
3 & Muara sungai/Estuari \\
\hline
\end{tabular}

Sumber: Agustina (2014) 


\section{Pengambilan Sampel Kepiting Biola (Uca spp.)}

Sampel yang diamati adalah Uca spp. yang berada dalam plot dari tali rafia berukuran $1 \mathrm{~m} \times 1 \mathrm{~m}$ untuk dilakukan penghitungan (Hamidah, 2014). Pengambilan data Uca spp. dilakukan pada pagi hari antara pukul $09.00-13.00$ WIB saat air laut surut. Hal ini dimaksudkan untuk mempermudah penangkapan Uca spp. Penghitungan Uca spp. dilakukan \pm 10 menit setelah Uca spp. berada dalam plot. Uca spp. yang berada pada permukaan substrat diambil menggunakan tangan, sedangkan yang berada dalam lubang diambil dengan bantuan sekop.

\section{Identifikasi Kepiting Biola (Uca spp.)}

Teknik pengidentifikasian jenis Uca spp. dapat dilakukan dengan cara melihat bentuk/karakteristik/ciri umum dari bentuk tubuh, untuk lebih jelasnya agar mengurangi tingkat kesalahan dalam pengidentifikasian kita dapat menggunakan gambar/referensi jenis - jenis dari buku atau literatur spesies Uca spp. yang ada. Untuk Uca spp. identifikasi dapat dilakukan dengan melihat, membandingkan bentuk dan pada capit besar pada setiap spesies kemudian dilihat warna spesies. Hasil pengamatan dibandingkan serta dideskripsikan dengan identifikasi yang dilakukan Murniati (2010) dan diperkuat dengan buku identifikasi Crane (1975).

\section{Suhu}

\section{Parameter Lingkungan}

Pada pengukuran suhu diukur dengan menggunakan alat berupa termometer yang nantinya berfungsi untuk mengukur kondisi suhu perairan pada tiga plot setiap transek. Cara pengukurannya yaitu termometer dicelupkan pada kedalam air yang diteliti di setiap lokasi penelitian, kemudian termometer didiamkan \pm 1-2 menit hingga mencapai angka konstan atau tidak berubah - ubah. Skala yang dicapai air raksa mununjukkan suhu perairan.

\section{Salinitas}

Pengukuran salinitas dilakukan pada tiga plot setiap stasiun. Mengukur salinitas dengan menggunakan refraktometer. Sampel air laut diambil pada setiap plot masing-masing transek lalu diteteskan pada kaca refraktometer lalu diarahkan sumber cahaya. Hasil data dicatat pada lembaran data.

\section{Derajad Keasaman (pH)}

Pengukuran $\mathrm{pH}$ dilakukan pada tiga plot setiap stasiun. Pada pengukuran $\mathrm{pH}$ menggunakan alat yang disebut dengan soil tester pada masing-masing plot pada setiap transek. Lalu tunggu 1-3 menit hingga nilai pada layar berhenti untuk melihat nilai $\mathrm{pH}$ yang sesungguhnya lalu dicatat pada tabel pengamatan.

\section{Substrat}

Pengambilan substrat dilakukan pada tiga plot setiap stasiun. Penggolongan jenis substrat dengan menggunakan metode ayakan kering, yaitu dengan cara mengambil sample substrat pada masing-masing plot pada setiap stasiun dengan menggunakan skop atau tangan lalu sample tersebut dikeringkan. Analisis substrat berdasarkan bentuk ukuran butir sedimen menurut Skala Wentworth dan Diagram Shepard. 


\section{Kandungan Bahan Organik}

Pengambilan bahan organik dilakukan pada tiga plot setiap stasiun. Cara mengambil sample bahan organik pada masing-masing plot pada setiap stasiun dengan menggunakan skop atau tangan lalu dimasukkan ke dalam botol sempel dan di analisis di laboratorium.

\section{Kelimpahan Jenis}

\section{Analisis data}

Penentuan kelimpahan jenis (Taqwa, 2010) melalui rumus :

Keterangan :

$$
\mathrm{Xi}=\frac{n i}{A}
$$

$\mathrm{Xi}=$ Kelimpahan Jenis $\mathrm{i}$

$\mathrm{Ni}=$ Jumlah Jenis $\mathrm{i}$

$A=$ Luas Wilayah Pengambilan Sampel $\left(\mathrm{m}^{2}\right)$

\section{Indeks Keanekaragaman Jenis}

Keanekaragaman ditentukan dengan menggunakan rumus kenekaragaman menurut Shannon-Wiener (1984) dalam Bengen (2000) sebagai berikut :

$$
\mathrm{H}^{\prime}=-\sum \frac{n i}{N} \log ^{2} \frac{n i}{N}
$$

Keterangan :

$\mathrm{H}^{\prime} \quad=$ Indeks keanekaragaman jenis

ni = Jumlah individu masing-masing jenis

$\mathrm{N}=$ Jumlah total individu semua jenis

$\log ^{2}=3,3219$

Tabel 4. Kriteria Indeks Keanekaragaman Jenis

\begin{tabular}{cc}
\hline Nilai & Kategori \\
\hline Jika nilai $\mathrm{H}^{\prime}<1,5$ & Maka keanekaragaman jenis rendah \\
Jika nilai $1,5<\mathrm{H}^{\prime}<3,5$ & Maka keanekaragaman jenis sedang \\
Jika nilai $\mathrm{H}^{\prime}>3,5$ & Maka keanekaragaman jenis tinggi \\
\hline
\end{tabular}

Sumber : Shannon-Wiener (1984)

\section{Indeks Keseragaman}

Keseragaman dapat dikatakan sebagai kesimbangan, yaitu komposisi individu tiap jenis spesies yang terdapat dalam suatu komunitas. Keseragaman diperoleh dari hubungan antara keanekaragaman $\left(\mathrm{H}^{\prime}\right)$ dengan nilai maksimal, yaitu dengan rumus indeks keseragaman (Krebs, 2014)

Keterangan :

$$
\mathrm{E}=\frac{H^{\prime}}{\text { Hmaks }}
$$

$\mathrm{H}_{\text {maks }}=\ln \mathrm{S}(\mathrm{S}=$ jumlah spesies $)$

$\mathrm{E} \quad=$ Indeks Keseragaman

$\mathrm{H}^{\prime} \quad=$ Indeks Keanekaragaman 
Tabel 5. Kategori Indeks Keseragaman

$\begin{array}{cc}\text { Nilai } & \text { Kategori } \\ 0<\mathrm{E} \leq 0,5 & \text { Kondisi tertekan dan keseragaman rendah } \\ 0,5<\mathrm{E} \leq 0,75 & \text { Kondisi kurang stabil dan keseragaman sedang } \\ 0,75<\mathrm{E} \leq 1,0 & \text { Kondisi stabil dan keseragaman tinggi }\end{array}$

Sumber : Krebs, 2014

\section{Indeks Dominansi}

Menurut Odum (1993) status kondisi komunitas dapat ditentukan dengan menggunakan indeks dominansi.

Keterangan :

$$
\mathrm{D}=\sum_{i=1}^{s}\left[\frac{N i}{N}\right]^{2}
$$

$\mathrm{D}=$ Indeks dominansi-Simpson

$\mathrm{Ni}=$ Jumlah individu jenis ke-i

$\mathrm{N}=$ Jumlah total individu

$S=$ Jumlah jenis

Tabel 6. Kategori Indeks Dominansi

\begin{tabular}{cc}
\hline Nilai & Kategori \\
\hline Jika nilai $0<D \leq 0,5$ & Maka dominansi rendah \\
Jika nilai $0,5<D \leq 0,75$ & Maka dominansi sedang \\
Jika nilai $0,75<D \leq 1,00$ & Maka dominansi tinggi \\
\hline
\end{tabular}

Sumber : Odum (1993)

\section{Kandungan Bahan Organik}

Untuk mengetahui kandungan bahan organik total dilakukan perhitungan menurut Pett (1993), dengan rumus sebagai berikut :

Bahan organik $(\%)=(\mathrm{W}-\mathrm{W} 2) / \mathrm{W} \times \mathrm{fk} \times \mathrm{fki} \times 100$

C-organik $(\%)=$ bahan organic $\times 0,58$

Dimana :

$\mathrm{W} 2$ = berat abu dalam gram

$\mathrm{W}$ = berat contoh dalam gram

$\mathrm{fki}=$ faktor koreksi bahan ikutan $=(100-\%$ bahan ikutan $) / 100$

$\mathrm{fk}=$ faktor koreksi kadar air $=100 /(100-\%$ kadar air $)$

0,58 = faktor konversi bahan organik ke karbon

Menurut Hardjowigeno (2003), sifat kimia tanah berdasarkan kandungan bahan organik sebagai menjadi lima (Tabel 7).

Tabel 7. Sifat Kimia Tanah Berdasarkan Kandungan bahan organik

\begin{tabular}{ccc}
\hline No. & $\begin{array}{c}\text { Kimia tanah berdasarkan kandungan } \\
\text { bahan organik }\end{array}$ & Kategori \\
\hline 1 & $<1,00 \% \mathrm{C}$ & Sangat rendah \\
2 & $1,00-2,00 \% \mathrm{C}$ & Rendah
\end{tabular}




\begin{tabular}{ccc}
3 & $2,01-3,00 \%$ C & Sedang \\
4 & $3,01-5,00 \%$ C & Tinggi dan \\
5 & $>5,00 \%$ C & Sangat Tinggi \\
\hline
\end{tabular}

Sumber : Hardjowigeno (2003)

\section{HASIL DAN PEMBAHASAN}

\section{Gambaran Umum Lokasi Penelitian}

Pulau Enggano memiliki iklim basah tropis yang sangat dipengaruhi oleh laut. Menurut zona Agroklimat Oldeman, iklim di Pulau Enggano termasuk zona Agroklimat B-1, dengan curah hujan pada bulan kering lebih dari $100 \mathrm{~mm}$, sedangkan pada bulan basah lebih besar dari $200 \mathrm{~mm}$. Curah hujan tahunan di Pulau Enggano cukup tinggi yaitu diatas $3.230 \mathrm{~mm}$ setiap tahunnya. Kelembaban nisbi umumnya diatas $80 \%$, sedangkan suhu udara berkisar antara $24^{\circ} \mathrm{C}$ sampai $34^{\circ} \mathrm{C}$ (Ta'alidin $d k k$., 2003 dalam Agustini, 2014).

Desa Kahyapu mempunyai luas wilayah $\pm 8.565 \mathrm{Ha}$. Desa Kahyapu mempunyai topografi lahan sebagian besar daratan rendah dengan ketinggian daratan $\pm 0-10$ meter dari permukaan laut (Hasil wawancara dengn Kepala Desa).

Hutan mangrove di Desa Kahyapu termasuk baik atau belum rusak karena setelah berlakunya hukum adat dan masuknya hukum publik yang seperti sekarang. Menurut Agustina (2014), menyatakan bahwa jenis mangrove yang dominan yang ada di Desa Kahyapu Pulau Enggano yaitu jenis Bruguiera, Xylocarpus, Rhizophora.

Pengambilan data yang dilakukan di Desa Kahyapu pada 3 stasiun penelitian dengan titik koordinat $102^{\circ} 22^{\prime} 18^{\prime \prime}$ LU dan $5^{\circ} 26^{\prime} 44^{\prime \prime}$ LS (stasiun 1) $102^{\circ} 22^{\prime} 20,2^{\prime \prime}$ LS dan $5^{\circ} 26^{\prime} 33^{\prime \prime}$ LS (stasiun 2) 102²3'24,7" LU dan 06²3'44,2” LS (stasiun 3).

\section{Jenis Kepiting Biola (Uca Spp.)} 9).

Berdasarkan hasil penelitian terdapat empat jenis kepiting biola (Uca spp.) (Tabel Tabel 9. Jenis Kepiting Biola (Uca spp.)

\begin{tabular}{clccc}
\hline No. & Jenis Kepiting Biola & Stasiun I & Stasiun II & Stasiun III \\
\hline 1. & Uca vocans & $\sqrt{ }$ & $\sqrt{ }$ & $\sqrt{ }$ \\
2. & Uca chlorophthalmus & $\sqrt{ }$ & $\sqrt{ }$ & $\sqrt{ }$ \\
3. & Uca dussumieri & $\sqrt{ }$ & $\sqrt{ }$ & $\sqrt{ }$ \\
4. & Uca coarctata & $\sqrt{ }$ & $\sqrt{ }$ & $\sqrt{ }$ \\
\hline
\end{tabular}

Pada penelitian ini di ekosistem mangrove Desa Kahyapu Pulau Enggano ada empat jenis kepiting biola (Uca spp.) yang didapat yaitu Uca vocans, Uca chlorophthalmus, Uca dussumeiri, dan Uca coarctata. Disetiap stasiun terdapat empat spesies kepiting biola (Uca spp.) tersebut. 


\section{Uca vocans}

Daktilus pada capit besar Uca vocans lebih panjang dibandingkan manusnya. Bentuk dektilus ini lebar dan datar tanpa lekukan panjang pada permukaan luar. Manus tanpa tonjolan besar, polleks lebar dan pipih dengan lekukan panjang di tengah yang mendekati panjang polleks.

Uca Vocans berukuran tubuh 30-50 mm, karapas berbentuk trapesium berwarna kuning, orbit melekuk tajam (Gambar 8.a), merus dan carpus berwana kuning, manus berwarna kuning, kasar, dactyl berwarna putih pollex berwarna kuning (Gambar 8.b). Menurut Murniati (2010) bahwa ukuran lebar karapas jantan dewasa mencapai $25 \mathrm{~mm}$, sedangkan betina dewasa mencapai $22,5 \mathrm{~mm}$ dan hidup pada substrat berpasir. Menurut Crane (1975), penyebaran Uca vocans meliputi Malaysia, Indonesia, Philipina dan Kepulauan Nansei (Ryukyu).

\section{Uca chlorophtalmus}

Uca chlorophtalmus memiliki bentuk Orbit melekuk tajam, tepi anterolateral pendek, tepi dorsolateral tampak jelas. Di bagian luar pangkal pollex capit besar terdapat cekungan berbentuk segitiga (Murniati, 2010). Secara umum warna pada Uca chlorophtalmus didominasi oleh warna medium purple dan red orange. Warna tersebut terlihat jelas pada bagian karapas dan manus pada bagian capit Uca chlorophtalmus jantan. Hal ini sejalan dengan Nontji (2005) dalam Wulandari (2013) yang menyatakan bahwa kepiting biola yang warnanya sangat mencolok akan kontras dengan lumpur yang biasanya berwarna gelap.

\section{Uca dussumieri}

Menurut Murniati (2010) capit besar Uca dussumieri tertutup oleh granula dengan ukuran yang bervariasi; polleks dan daktilus panjang, dengan gigi-gigi kecil yang menempel satu dengan lainnya mulai dari bagian tengan sampai ujung; daktilus mempunyai dua lekukan memanjang pada permukaannya.

Uca dussumieri berukuran tubuh 30-74 mm, karapas berbentuk trapezium berwarna kuning kecoklatan, orbit melekuk tajam, merus dan carpus berwarna oranye, manus bagian dorsal berwarna cokelat keputihan, bagian ventral berwarna orange, kasar, dactyl berwarna putih dan pullex berwarna putih

Bentuk capit Uca dussumieri lebih ramping (pipih) sehingga terlihat lebih panjang dari bagian luas karapasnya. Selain itu juga terlihat gigi pada jari-jari Uca dussumieri yang lebih rata serta memiliki ukuran yang hampir sama. Tsukamoto $d k k$. (2000) menambahkan bahwa jari-jari pada capit Uca dussumieri menempel antara satu dan yang lainnya mulai dari bagian tengah sampai ke ujung dan jari yang dapat digerakkan memiliki 2 lekukan memanjang pada permukaannya.

\section{Uca coartata}

Uca coartata berukuran tubuh 30-75 mm, karapas berbentuk trapezium berwarna hitam, pada bagian ventral terdapat dua titik besar berwarna putih, orbit melekuk tajam, carpus tungkai belakang berwarna putih dibagian tengah, merus berwarna kuning, carpus berwarna putih, manus bagian dorsal bewarna putih, bagian ventral berwarna merah, kasar, dactyl dan pollex berwarna putih.

Menurut Crane (1975) Uca coartata memiliki warna hitam dan orange, karapas berwarna hitam, kadang-kadang terdapat titik-titik, bulat/oval, berwarna putih. 
Gambar capit hingga orange pucat dibagian branchict. Sebaran kepiting ini mulai dari Sumatera sampai Kepulauan Fiji, Philipina, Australia dan New Gunes.

\section{Kelimpahan Jenis}

Berdasarkan hasil penelitian kelimpahan jenis dan kelimpahan total kepiting biola (Uca spp.) yang paling tinggi pada stasiun I. Ini di karenakan substrat pada stasiun I yaitu berpasir. Substrat berpasir ini cocok dan baik untuk kehidupan kepiting biola (Uca spp.). Pratiwi (2010) mengatakan bahwa spesies Uca spp. umumnya hidup di habitat berpasir dan berlumpur.

Kelimpahan jenis dan kelimpahan total kepiting biola (Uca spp.) yang tinggi di stasiun I dapat juga dipengaruhi oleh kondisi kerapatan tumbuhan mangrove yang masih baik. Hasil penelitian Agustina (2014) menjelaskan bahwa nilai kerapatan jenis mangrove tertinggi pada tingkatan pohon sebanyak 489 pohon/ha.

Secara umum Uca dussumieri paling banyak ditemukan di tiga stasiun karena habitat cocok (substrat). Menurut Weis and Weis (2004), Uca dussumieri hidup di habitat dengan kandungan bahan organik yang tinggi. Berdasarkan hasil analisis, kandungan bahan organik di ketiga stasiun termasuk tinggi. Machinthos (1982), menambahkan bahwa Uca dussumieri mampu beradaptasi secara baik terhadap faktor-faktor lingkungan yang sangat luas yang ada di ekosistem. Sehingga kepiting jenis ini ditemukan melimpah di seluruh stasiun yang memiliki salinitas yang berbeda.

\section{Indeks Keanekaragaman Jenis}

Hasil perhitungan dengan rumus indeks keanekargaman jenis yang dilakukan menghasilkan data bahwa keanekaragaman jenis pada ketiga stasiun tergolong rendah $\left(H^{\prime}<1,5\right)$. Rendahnya keanekaragaman pada semua stasiun menunjukkan komunitas memiliki kompleksitas rendah, karena dalam komunitas tidak banyak terjadi interaksi antar jenis. Komunitas dengan keanekaragaman jenis rendah, sedikit interaksi antar jenis yang melibatkan transfer energi, predasi, dan kompetisi. Odum (1996) menjelaskan keanekaragaman jenis cenderung rendah dalam ekosistem yang secara fisik terkendali (sasaran faktor pembatas fisika kimia yang kuat). Keanekaragaman rendah adanya jenis yang ditemukan di lokasi penelitian sedikit. Menurut Odum (1993) keanekaragaman ditandai dengan banyaknya spesies yang membentuk komunitas baru semakin banyak jumlah spesies maka semakin tinggi keanekaragaman.

\section{Indeks Keseragaman}

Untuk mengetahui seberapa besar kesamaan penyebaran jumlah individu setiap jenis digunakan indeks keseragaman, yaitu dengan cara membandingkan indeks keanekaragaman dengan nilai maksimumnya. Semakin seragam penyebaran individu antar spesies maka keseimbangan ekosistem akan semakin meningkat (Ludwig and Reynolds, 1988).

Berdasarkan Tabel 11 nilai indeks keseragaman kepiting biola (Uca spp.) seluruh stasiun tinggi. Tabel 11 dapat dilihat bahwa masing-masing indeks keseragaman mendekati 1 dengan kriteria menurut Krebs (2014), $0<\mathrm{E}<0,4$ menunjukkan keseragaman rendah, $0,4<E<0,6$ menunjukkan keseragaman sedang dan $E>0,6$ menunjukkan keseragaman tinggi, artinya penyebaran individu tersebut mendekati merata atau tidak ada spesies yang mendominasi. Odum (1993) menyatakan bahwa indeks keseragaman yang tinggi menunjukkan bahwa ekosistem tersebut berada 
dalam kondisi yang stabil. Keseragaman populasi akan kecil jika nilai E semakin kecil, yang artinya penyebaran jumlah individu setiap jenisnya tidak sama dan ada kecenderungan satu jenis tertentu mendominasi populasi tersebut. Semakin tinggi penyebaran individu antar spesies, maka keseimbanagan ekosistem akan makin meningkat (Krebs, 1989).

\section{Indeks Dominansi}

Indeks dominansi merupakan nilai untuk memperoleh informasi mengenai jenis kepiting Uca spp. yang mendominasi pada suatu komunitas pada tiap habitat (Ludwig and Reynold, 1988).

Berdasarkan hasil perhitungan pada ketiga stasiun tersebut mempunyai indeks dominansi rendah. Menurut Odum (1996) indeks dominansi tinggi (jika nilai 0,75<D $\leq 1,00$ ), indeks dominansi sedang (jika nilai $0,5<\mathrm{D} \leq 0,7$ ) dan indeks dominansi rendah (jika nilai $0<D \leq 0,5$ ). Untuk nilai $D=1$ berarti terdapat jenis yang mendominasi jenis lainnya atau komunitas berada dalam kondisi labil karena terjadi tekanan ekologis. Selanjutnya Indriyanto (2006) menambahkan bahwa apabila indeks dominansi tinggi, maka dominansi (penguasaan) terpusat (terdapat) pada satu spesies. Tetapi apabila nilai indeks dominansi rendah, maka dominansi terpusat (terdapat) pada beberapa spesies. Tidak adanya spesies Uca spp. yang mendominansi di ekosistem mangrove Desa Kahyapu tersebut menunjukan bahwa perairan tersebut cukup sesuai untuk kehidupan kepiting biola (Uca spp.).

\section{Parameter Lingkungan Suhu}

Suhu adalah salah satu parameter fisika yang penting dalam pertumbuhan dan kehidupan kepiting biola (Uca spp.). Berdasarkan hasil pengukuran yang dilakukan, suhu yang bagus untuk kehidupan kepiting biola (Uca spp.) adalah semua stasiun. Perairan pada ekosistem mangrove ini baik untuk tempat hidup kepiting biola (Uca spp.). Menurut Cholik (2005), suhu yang sesuai untuk kehidupan bagi kepiting biola (Uca spp.) adalah $18^{\circ} \mathrm{C}-35^{\circ} \mathrm{C}$, sedangkan suhu ideal adalah $25^{\circ} \mathrm{C}-30^{\circ} \mathrm{C}$.

\section{Salinitas}

Salinitas merupakan parameter lingkungan yang mempengaruhi proses biologi dan secara langsung mempengaruhi kehidupan organisme termasuk kepiting biola (Uca spp.). Salinitas berpengaruh terhadap reproduksi, distribusi dan osmoregulasi. Perubahan salinitas tidak langsung berpengaruh terhadap perilaku biota tetapi berpengaruh terhadap perubahan sifat kimia air (Brotowidjoyo, et al. 1995). Salinitas yang optimum bagi kepiting biola (Uca spp.) berkisar antara 23-26 ppt (Ramelan, 1994). Salinitas mempengaruhi jumlah makanan yang dikomsumsi dan daya kelangsungan hidup (Faud, 2005).

Berdasarkan hasil dari data pengamatan di Laboratorium IImu Tanah maka didapat substrat berlumpur. Nontji (1987) mengatakan bahwa di lumpur-lumpur lunak di dasar hutan mangrove yang tidak terlalu rimbun juga banyak ditemukan kepiting biola (Uca spp.).

\section{Derajat Keasaman $(\mathrm{pH})$}

Hasil pengukuran $\mathrm{pH}$ berkisar antara 7,5-7,74 dan sesuai untuk pertumbuhan. Pengukuran $\mathrm{pH}$ rata-rata di lokasi penelitian memiliki kisaran yang tidak jauh berbeda 
pada setiap stasiun. Pada stasiun 1 rata-rata salinitasnya sebesar 7,5 , stasiun 2 ratarata sebesar 7,6, stasiun 3 rata-rata sebesar 7,74. Setiap stasiun tidak mengalami perbedaan $\mathrm{pH}$ yang begitu drastis.

Nilai $\mathrm{pH}$ mempengaruhi tingkat kesuburan perairan karena mempengaruhi kehidupan jasad renik. Perairan yang asam cenderung menyebabkan kematian demikian juga pada $\mathrm{pH}$ yang mempunyai nilai terlalu basa, hal ini disebabkan konsentrasi oksigen akan rendah sehingga aktivitas pernafasan tinggi dan berpengaruh terhadap menurunnya nafsu makan (Ghofron dan Kordir, 2005 dalam Agus, 2008).

\section{Substrat}

Substrat merupakan faktor lingkungan yang terpenting bagi kehidupan Uca spp., sebab substrat merupakan habitat berpijah (spawning ground), mencari makan (feeding ground), dan habitat asuh (nursery ground). Tipe substrat merupakan perbandingan relatif (\%) antara fraksi-fraksi debu, liat, dan pasir. Berdasarkan hasil pengamatan di Laboratorium IImu tanah dan hasil analisis skala Wentworth dan Diagram Shepard bahwa substrat di stasiun I sampai stasiun III berpasir, sesuai dengan habitat kepiting biola (Uca spp.). Menurut Hamidy (2010) tanah berpasir mempermudah Uca spp. untuk membuat lubang dan kandungan bahan organiknya juga melimpah, disebabkan kandungan serasah yang tinggi.

\section{Kandungan Bahan Organik}

Bahan organik merupakan sumber nutrien bagi biota perairan yang pada umumnya terdapat pada substrat dasar sehingga ketergantungannya terhadap bahan organik sangat besar (Amin et al., 2012). Ketersediaan bahan organik dapat memberikan variasi yang besar terhadap kelimpahan organisme yang ada.

Nilai kandungan bahan organik pada masing-masing stasiun cenderung tidak bervariasi jauh dan erat kaitannya dengan jenis substrat. Pada stasiun I sampai stasiun III kandungan bahan organik selama penelitian berkisar 12,08\% - 12,34\% dimana ketiga stasiun tersebut sangat tinggi kandungan bahan organiknya. Menurut Hardjowigeno (2003), sifat kimia tanah jika kandungan bahan organik $>5,00 \%$ maka termasuk kategori sangat tinggi.

\section{KESIMPULAN}

Kepiting Biola (Uca spp.) yang terdapat di kawasan hutan mangrove Desa Kahyapu Pulau Enggano di temukan empat spesies yaitu Uca vocans, Uca chorophthalmus, Uca dussumieri dan Uca coarctata. Kelimpahan kepiting biola tertinggi pada stasiun I, diikuti stasiun III dan stasiun II. Jenis kepiting biola yang paling tinggi adalah spesies Uca dussumieri. Kelimpahan kepiting biola (Uca spp.) yang paling sedang pada stasiun I dan yang paling rendah pada stasiun II dan stasiun III. Indeks keanekaragaman jenis pada 3 stasiun tergolong rendah $\left(H^{\prime}<1,5\right)$, menunjukkan komunitas rendah. Indeks keseragaman pada tiga stasiun kategori tinggi dan kondisi stabil. Indeks dominansi pada ketiga stasiun merupakan kategori rendah. Secara umum parameter kualitas air (suhu, pH, salinitas, kandungan bahan organik, dan substrat) sesuai untuk kehidupan kepiting biola. 
EISSN: 2527-5186

Jurnal Enggano Vol. 2, No. 1, April 2017: 11-24

\section{DAFTAR PUSTAKA}

Agus, M. 2008. Analisis Carrying Tambak pada Sentra Kepiting Biola Di Kabupaten Pemalang Jawa tengah. Tesis. MSDP Universitas Diponegoro Semarang.

Agustini, N. 2014. Struktur Komunitas Ekosistem Mangrove di Desa Kahyapu Pulau Enggano. Skripsi. Program Studi IImu Kelautan Jurusan Peternakan Fakultas Pertanian Universitas Bengkulu. Bengkulu.

Amin, I. N. dan Marwan. 2012. Kandungan Bahan Organik Sedimen dan Kelimpahan Makrozoobenthos Sebagai Indikator Pencemaran Perairan Pantai Tanjung Uban Kepulauan Riau. Laboratorium Kimia Laut Fakultas Perikanan dan IImu Kelautan Universitas Riau. Pekanbaru.

Bengen, D.G. 2000. Pedoman Teknis Pengenalan dan Pengelolaan Ekosistem Mangrove, Pusat Kajian Sumberdaya Pesisir dan Lautan. IPB. Bogor.

Crane, Jocelyn. 1975. Fiddler Crabs of the World Ocypoddae Genus Uca. Princeton University Press. America.

Hamidy, R. 2010. Struktur Keragaman Komunitas Kepiting di Kawasan Hutan Mangrove Fakultas Kelautan, Universitas Riau, Desa Purnama Dumai. IImu Lingkungan. V 4 (2): 81-91.

Hamidah Afreni, Melki Fratiwi, Jodion Siburian. 2014. Kepadatan Kepiting Biola (Uca sp.) Jantan dan Betina di desa Tungkali I Tanjung Jabung Barat. Jurnal Penelitian Universitas Jambi Seri Sains. 16 (2) : 43-50.

Hardjowigeno, S. 2003. IImu Tanah. Akademika Pressindo. Jakarta.

Hasan, R. 2014. Populasi dan Mikrohabitat Kepiting Genus Uca di Kawasan Konservasi Mangrove Pantai Panjang, Bengkulu. Seminar Nasional XI Pendidikan Biologi FKIP UNS.

Indriyanto. 2010. Ekologi Hutan. Bumi Aksara. Jakarta.

Kasmiruddin, Rusdi Hasan, Ade Kurnia Wardani. 2014. Morfometri dan Alometri Kepiting Biola Uca Perplexa Yang Terdapat Pada Vegetasi Mangrove Di Pulau Baai, Bengkulu. Skripsi. Seminar Nasional XI Pendidikan Biologi FKIP UNS.

Kim, T.W., Kil W.K., Robert B.S., Jae C.C. 2004. Semilunar Courtship Rhytm of the Fiddler Crab Uca lactea in a Habitat with Great Tidal Variation. J. Ehol. 22:6368.

Kochl, V. and M. Wolff. 2002. Energy budget and ecological role of mangrove epibenthos in the Caete estuary, North Brazil. Mar Ecol Pro Ser. 228 (1) : 119130.

Krebs, C. J. 1989. Ecologycal methodology. Wm. C. Brown Publisher. Dubuque. 620 pp.

Krebs, J. C. 2014. Ecological Methodology. 3nd Edition. Published by AddisonWelsey.

Ludwig dan Reynold, 1988. Polychaetes and allies:the Southern synthesis. Fauna of Australia. Polychaeta, Myzostomida, Pogonophora, Echiura, Sipuncula. Melbourne: CSIRO.

Lusiana, D. 2015. Hubungan Kepadatan Kepiting Bakau (Scylla spp.) dengan Kerapatan Mangrove di Desa Kahyapu Kecamatan Enggano Bengkulu Utara. Skripsi. Program Studi Ilmu Kelautan Jurusan Peternakan Fakultas Pertanian Universitas Bengkulu. Bengkulu. 
Machintos, DJ. 1982. Ecologic and productivity of Malaysian mangrove crab population (Decapoda: Brachyura). Proc. As. Symp. Mangr. Env. - Res \& Management, $1982: 354-377$.

Murniati, D. C., 2010. Keanekaragaman Uca sp. Dari Segara-Anakan, Cilacap, Jawa Tengah Sebagai Pemakan Deposit. Fauna Indonesia. 9 (1) : 19-23.

Nontji. A. 2007. Laut Nusantara. Penerbit Djambatan : Jakarta

Odum, E.P.1993. Dasar-dasar Ekologi. Terjemahan Tjahjono Samingan. Yogyakarta : Gadjah Mada University Press.

Odum, E. P. 1996. Dasar-dasar Ekologi (EdisiKetiga).Gadjah Mada University Press. $697 \mathrm{hlm}$.

Peddy Andrian, Rusdi Hasan, Siti Darwa Suryani. 2014. Jenis - Jenis Dan Kepadatan Kepiting Biola (Uca sp.) Dikawasan Mangrove Desa Pasar Ngalam Kecamatan Air Periukan Kabupaten Seluma. Jilid 1. Skripsi . Bengkulu.

Pett, R. J. 1993. A collection of Laboratory Methods For Water and Sedimen Quality Parameter Report No. 13 Internasional Development Program at Australia University and Colleges. PT. Husfarm Dian Konsultant. 20 p.

Pratiwi, R. 2007. Jenis dan Sebaran Uca spp. (Crustacea: Decapoda: Ocypodidae) di Daerah Mangrove Delta Mahakam Kalimantan Timur. Jurnal Perikanan, V IX (2): 322-328

Rosenberg, M. S.,2000. The Comparative Claw Morphology, Phylogeny, and Behavior of Fiddler Crabs (Genus Uca). Ph.D. Thesis. Department of Ecology and Evolution, State University of New York at Stony Brook, Stony Brook, NY.

Romimohtarto, K dan S. Juwana. 2007. Biologi Laut Ilmu Pengetahuan tentang Biota Laut. Djambatan. Jakarta.

Senoaji, G., Riwandi., Cahyadinata, I., Hidayat, M. F., Suminar, R., Magdalena. 2006. Studi Daya Dukung Pemanfaatan dan Pengembangan Kepulauan Enggano. Kerjasama Bapedalda Provinsi Bengkulu dengan Pusat Penelitian Lingkungan Universitas Bengkulu.

Suprayogi, D. 2014. Keanekaragaman Kepiting Biola (Uca spp) di Desa Tungkal I Tanjung Jabung Barat. Biospesies. 7 (1) : $22-28$

Susanto, P. 2000, Pengantar Ekologi Hewan, Departemen Pendidikan Nasional, Jakarta.

Wirakusumah, Sambas. 2003. Dasar-dasar Ekologi; Menopang Pengetahuan IImuilmu Lingkungan. Jakarta: UI Press.

Wulandari, Tia. 2013. Morfologi Kepiting Biola (Uca spp.) di Desa Tungkal I Tanjung Jabung Barat Jambi. Biospecies. 6 (1) 6-14.

Weis, S.J., Weis, P. 2004. Behavior of four spesies of fiddler crabs, genus Uca, in southeast Sulawesi, Indonesia. Hydrobiologia. 5 (23) : 47-58. 